\title{
POTENSI FEMALE ATHLETE TRIAD PADA ATLET REMAJA PUTRI DEFISIENSI BESI
}

\author{
Female Athlete Triad Potential among Young Female Athletes with Iron Deficiency
}

\author{
Fillah Fithra Dieny ${ }^{1,2}$, Deny Yudi Fitranti ${ }^{1,2}$, Firdananda Fikri Jauharany ${ }^{1}$, A Fahmy Arif Tsani ${ }^{1,2}$ \\ ${ }^{1}$ Department of Nutritional Sciences, Faculty of Medicine, University of Diponegoro \\ ${ }^{2}$ Nutrition Research Center of the Faculty of Medicine \\ E-mail: fillahdieny@gmail.com
}

\begin{abstract}
The female athlete triad (FAT) is a syndrome that occurs in female athletes who have a combination of 3 related conditions and are associated with sports. The aimed of this study to analyze the relationship between iron deficiency and the state of the female athlete triad (FAT) in female athletes. The design of this study was cross sectional with 80 subjects of female athletes aged 12-18 years from various sports, who were taken by simple random sampling. The research was conducted at the Central Java Student Center for Education and Sports Training (BPPLOP). Bivariate analysis was performed using the Spearman test. Based on Ferritin, as many as 15 subjects $(18.25 \%)$ had iron deficiency anemia, and FAT syndrome was not found in the subjects, however, when each sign was seen, 20 percent were classified as polimenorrhea and oligomenorrhea, and 37.5 percent experienced eating disorders. There were a significant relationship between iron deficiency based on serum ferritin $(p=0.015 ; r=0.273)$ and $\mathrm{Hb}$ levels $(p=0.002 ; r=0.337$ ) with the component of athlete's bone density. However, iron deficiency (based on serum Ferritin and $\mathrm{Hb}$ levels) did not show a significant association with menstrual cycle disorders and eating disorders $(p<0.05)$. Female Athlete Triad has not been found among subjects, but athletes have experienced eating behavior disorders, menstrual cycle disorders and the risk of low bone density. Iron deficiency is associated with decreased bone density in young female athletes.
\end{abstract}

Keywords: athletes, female adolescents, iron deficiency, female athlete triad

\section{ABSTRAK}

Female athlete triad (FAT) merupakan suatu syndrom yang terjadi pada atlet wanita yang memiliki kombinasi dari 3 kondisi yang saling berkaitan, dan berhubungan dengan olahraga. Tujuan penelitian untuk menganalisis hubungan defisiensi besi dengan keadaan female athelete triad (FAT) pada atlet remaja putri. Desain penelitian ini adalah cross-sectional dengan 80 subjek atlet putri berusia 12-18 tahun dari berbagai cabang olahraga yang diambil secara simple random sampling. Penelitian dilakukan di Balai Pemusatan Pendidikan dan Latihan Olahraga Pelajar (BPPLOP) Jateng. Analisis univariat untuk mendeskripsikan data berupa distribusi dan persentase. Analisis bivariat dilakukan menggunakan uji Spearman. Berdasarkan data serum ferritin, sebanyak 15 subjek (18,25\%) mengalami anemia defisiensi besi, namun belum ditemukan kejadian FAT pada subjek, tetapi bila dilihat masing masing tanda sebanyak 20 persen tergolong polimenorea dan oligomenorea, serta 37,5 persen mengalami gangguan perilaku makan. Ada hubungan yang signifikan antara defisiensi besi berdasarkan serum ferritin $(p=0,015 ; r=0,273)$ dan kadar $\mathrm{Hb}(p=0,002 ; r=0,337)$ dengan komponen kepadatan tulang atlet. Namun defisiensi besi (bedasarkan serum Ferritin dan Kadar $\mathrm{Hb}$ ) tidak menunjukkan hubungan yang signifikan dengan gangguan siklus menstruasi dan gangguan perilaku makan $(p<0,05)$. FAT belum ditemukan pada atlet remaja putri, namun atlet sudah ada yang mengalami gangguan perilaku makan, gangguan siklus menstruasi dan risiko kepadatan tulang rendah. Defisiensi besi berhubungan dengan menurunnya kepadatan tulang atlet remaja putri.

Kata kunci: atlet, remaja putri, defisiensi besi, female athlete triad (FAT) 


\section{PENDAHULUAN}

D alam beberapa dasawarsa terakhir terjadi peningkatan partisipasi wanita dalam olahraga kompetitif. ${ }^{1}$ Peningkatan partisipasi ini mendatangkan dampak yang positif dalam dunia olahraga dari segi peningkatan kualitas kompetisi. Walaupun demikian, semakin disadari bahwa kegiatan fisik dengan intensitas tinggi juga dapat mengakibatkan dampak negatif bagi kesehatan mental, sosial maupun fisiologis atlet. ${ }^{2}$

Atlet remaja putri merupakan kelompok rentan terjadi masalah gizi. Hal ini disebabkan karena pada periode remaja seharusnya memerlukan gizi yang baik untuk menunjang proses tumbuh kembang yang meningkat pesat (growth spurt), di sisi lain atlet remaja putri juga dituntut tampil optimal dan berprestasi pada saat kompetisi berlangsung. ${ }^{3}$

Salah satu kasus defisiensi zat gizi mikro yang dilaporkan banyak terjadi pada atlet wanita adalah defisiensi zat besi. ${ }^{4}$ Terdapat penelitian yang melaporkan bahwa defisiensi zat besi yang diikuti dengan anemia ataupun tidak pada atlet akan menyebabkan gangguan pada fisiologis tubuh, terutama pada fungsi otot dan kapasitas kerja maksimum. ${ }^{5-8}$ Tidak hanya berpengaruh pada performa, defisiensi besi yang terjadi pada atlet remaja putri juga berisiko menimbulkan masalah gizi pada periode berikutnya, yaitu prakonsepsi, hamil dan menyusui. Tantangan anemia pada remaja putri dari 37,1 persen pada Riskedas 2013 justru mengalami peningkatan menjadi 48,9 persen pada Riskesdas 2018, dengan proporsi anemia ada di kelompok umur 15-24 tahun dan 25-34 tahun.

Selain defisiensi besi, masalah gizi yang dihadapi atlet adalah rendahnya asupan makanan sehingga atlet mengalami kekurangan energi dan lemak yang dapat berpengaruh pada hormon reproduksinya. Gangguan hormon reproduksi pada atlet putri dapat mengakibatkan amenorrhea, tidak hanya itu dalam jangka waktu yang panjang atlet putri juga dapat mengalami osteoporosis karena hormon reproduksi terutama esterogen berpengaruh pada proses remodeling tulang yang terdiri dari proses pembentukan tulang (bone formation) dan pembongkaran tulang (bone resorption). ${ }^{9}$

Female athlete triad (FAT) merupakan suatu syndrom yang terjadi pada atlet wanita yang memiliki kombinasi dari tiga kondisi yang saling berkaitan, dan berhubungan dengan olahraga. Tiga kondisi yang saling terkait ini adalah penyimpangan perilaku makan, gangguan menstruasi, dan osteoporosis..$^{10} F A T$ dialami oleh atlet putri yang membutuhkan bentuk tubuh ramping dan berat badan yang ringan untuk mencapai penampilan yang optimal, seperti atlet lari, senam, dan renang. ${ }^{11}$ Penelitian di California pada 170 atlet putri menemukan sebanyak 1,2 persen subjek mengalami FAT dan sebanyak 5,9 persen subjek memiliki dua dari tiga kriteria FAT.12 Penelitian yang dilakukan di Amerika pada atlet remaja putrid usia 13-18 tahun mengemukakan terdapat 4,3 persen atlet putri tergolong FAT. Prevalensi FAT pada atlet remaja putri di Indonesia belum diketahui. ${ }^{13}$

Apabila seorang atlet mengalami penyimpangan perilaku makan, hal ini akan memengaruhi asupan energi. Kurangnya asupan energi menyebabkan menurunnya frekuensi dorongan hormon lutein yang berfungsi sebagai pemicu ovulasi. ${ }^{14}$ Amenorrhea merupakan hasil dari respon adaptasi tubuh untuk menghemat penggunaan energi. Rendahnya jumlah leptin selama membatasi asupan kalori mungkin dapat menekan hipotalamus untuk mengeluarkan gonadotropin releasing hormon $(\mathrm{GnRH}) .{ }^{15}$ Konsekuensi yang harus diterima oleh atlet yang mengalami amenorrhea adalah gangguan fungsi dari hipotalamus dan pituitari yang menyebabkan menurunnya produksi hormon esterogen. Hormon esterogen memiliki peran yang besar untuk menjaga kekuatan kepadatan mineral tulang, dan rendahnya esterogen berhubungan dengan rendahnya kepadatan mineral tulang dan meningkatkan risiko osteoporosis. ${ }^{11}$

Penyimpangan perilaku makan sebagian besar dialami oleh atlet putri hal ini dikarenakan untuk membentuk tubuh yang ideal tidak cukup dengan melakukan latihan fisik tetapi juga dengan melakukan diet yang berbahaya untuk mencapai tujuannya. ${ }^{16}$ Diet yang berbahaya yang dilakukan atlet putri yang menyebakan mereka mengalami penyimpangan perilaku makan seperti anoreksia dan bulimia. ${ }^{17}$ Menurut penelitian di wisma atlet Ragunan Jakarta diketahui 1,2 persen atlet putri mengalami anoreksia nervosa, 4,9 persen mengalami bulimia nervosa, dan 43,9 persen mengalami 
Eating Disorder Not Otherwise Spesified (EDNOS). ${ }^{18}$ Penelitian pada 220 atlet putri di Edirne,Turki menunjukkan 37 atlet mengalami penyimpangan perilaku makan. ${ }^{19}$ Penelitian lain di Brazil menunjukkan 44,9 persen atlet renang mengalami penyimpangan perilaku makan ${ }^{20}$, sedangkan penelitian lain di Milwaukee menunjukkan 36 persen atlet wanita memiliki ketersediaan energi di dalam tubuh mereka yang rendah ( $\leq 45 \mathrm{kcal} / \mathrm{kg} / \mathrm{LBM})$, Amenorrhea berhubungan dengan ketersediaan energi didalam tubuh dalam kategori rendah $(\leq 30$ $\mathrm{kcal} / \mathrm{kg} / \mathrm{LBM}){ }^{13}$

Gangguan menstruasi pada atlet putri dapat disebabkan oleh meningkatnya latihan fisik dan rendahnya asupan zat gizi yang dapat menyebabkan perubahan fisiologi dalam kontrol endokrin pada sistem menstruasi yang akhirnya menyebabkan atlet amenorrhea. ${ }^{11}$ Menurut penelitian di Edirne, Turki 9,8 persen atlet mengalami amenorrhea, 0,9 persen atlet senam ritmik mengalami amenorrhea primer, dan 19,2 persen mengalami iregulasi menstruasi. ${ }^{19}$ Penelitian lain di California menyebutkan 16,1 persen atlet putri mengalami oligoamenorrhea dan 6,06 persen atlet mengalami amenorrhea sekunder. ${ }^{20}$ Menurut penelitian pada atlet renang di Brazil menunjukan 21,8 persen atlet tidak mengalami menarche dan 3,8 persen atlet tidak mengalami menarche sampai usia 14 tahun. ${ }^{20}$

Tipe dan durasi dari gangguan menstruasi, rendahnya persen lemak tubuh, ketidakcukupan asupan zat gizi, perubahan berat badan, dan menurunnya jumlah plasma esterogen pada wanita berhubungan langsung dengan perubahan kepadatan tulang. ${ }^{21}$ Jumlah plasma esterogen yang rendah pada wanita dapat menyebabkan berkurangnya kepadatan tulang secara cepat, baik karena rendahnya pembentukan tulang maupun tingginya pembongkaran tulang. ${ }^{21}$ Pelari yang sangat memperhatikan bentuk dan berat badannya menyebabkan terjadinya kebiasaan makan yang tidak normal. Hal ini dapat menimbulkan penyimpangan perilaku makan yang berisiko terhadap menurunnya masa tulang. ${ }^{17}$ Hasil penelitian di Swedia menunjukkan 10 persen pelari perempuan mengalami osteoporosis dan 50 persen mengalami osteopenia. ${ }^{10}$ Penelitian di Edirne,Turki 33,3 persen atlet putri mengalami osteoporosis dan 66,7 persen mengalami osteopenia. ${ }^{19}$ Penelitian di Brazil
15,4 persen atlet renang memiliki Bone Mineral Density (BMD) yang rendah. ${ }^{20}$

Terjadinya FAT menurut review tahun 2017 ternyata berkaitan dengan defisiensi besi yang banyak dialami atlet wanita. ${ }^{22}$ Suatu laporan menunjukkan mekanisme bagaimana defisiensi besi berinteraksi dengan setiap komponen dalam FAT. Ketersediaan energi dapat dipengaruhi oleh defisiensi besi melalui beberapa cara. Defisiensi besi kemungkinan berpotensi menyebabkan hipometabolik yang berhubungan dengan rendahnya status energi, memicu rendahnya asupan energi sehingga ketersediaan energi rendah. ${ }^{22}$ Fungsi reproduksi juga dapat dipengaruhi oleh defisiensi besi. Atlet yang mengalami defisiensi besi berisiko mengalami penurunan fungsi reproduksi. ${ }^{22}$ Terakhir, kepadatan tulang yang rendah juga dapat terpicu oleh kondisi defisiensi besi. Mekanisme defisiensi besi dengan kesehatan tulang melalui disregulasi growth hormone $(\mathrm{GH})$ atau IGF-1, hipoksia dan hipotiroid yang terkait dengan metabolisme kalsium. Perlu dicatat bahwa banyak dari potensi interaksi FAT berdasarkan pada kondisi anemia defisiensi besi. ${ }^{22}$

Namun penelitian/kajian tentang hal ini belum banyak ditemukan, terlebih di Indonesia. Padahal prevalensi anemia dan KEK pada kelompok WUS di Indonesia terutama remaja masih tinggi. Berdasarkan data Riskesdas tahun 2018, prevalensi KEK pada WUS hamil dan tidak hamil sebesar 31,8 persen, sedangkan prevalensi anemia pada remaja putri dari 37,1 persen pada Riskesdas 2013 justru mengalami peningkatan menjadi 48,9 persen pada Riskesdas 2018 dengan proporsi anemia ada di kelompok umur 15-24 tahun dan 25-34 tahun. ${ }^{23,24}$ Remaja putri merupakan calon ibu, apabila mengalami anemia ataupun KEK maka berpeluang menjadi "calon produsen anak stunting" di kemudian hari. Oleh sebab itu pemenuhan zat gizi makro maupun mikro pada atlet remaja putri perlu diperhatikan karena tidak hanya mempengaruhi penampilan dan prestasi olahraga, namun juga menentukan kualitas generasi penerus bangsa di masa depan. Berdasarkan hal tersebut, penelitian ini bertujuan untuk mengetahui potensi FAT pada atlet remaja dan kaitannya dengan defisiensi besi. kajian tentang FAT dan defisiensi besi pada atlet remaja putri yang merupakan 
kelompok rentan masalah gizi sangat perlu dilakukan.

\section{METODE PENELITIAN}

\begin{abstract}
Penelitian ini adalah penelitian observasional dengan rancangan penelitian cross-sectional yang dilakukan di Balai Pemusatan Pendidikan dan Latihan Olahraga Pelajar (BPPLOP) Jawa Tengah pada bulan Februari - Mei tahun 2019. Penelitian ini telah mendapatkan ethical clearance yang telah diajukan kepada Komite Etik Penelitian Fakultas Kedokteran Universitas Diponegoro/RSUP Dr. Kariadi Semarang dengan No. 343/EC/KEPK/FK-UNDIPNI/2019.
\end{abstract}

Besar sampel penelitian dihitung menggunakan rumus Lemeshow, yaitu $n=$ $Z^{2} p(1-p) / d^{2}$ dengan perhitungan dan koreksi dropout sebesar 10 persen. Pengambilan sampel penelitian dilakukan dengan menggunakan simple random sampling dan diperoleh 80 atlet yang memenuhi kriteria. Subjek berasal dari berbagai cabang antara lain atlet atletik, senam, renang, loncat indah, bola basket, bola voli, bulutangkis, tenis meja, tenis lapangan, taekwondo, pencak silat, dan judo.Seluruh cabang olahraga yang terdapat di BPPLOP Jawa Tengah didaftar, kemudian dilakukan skrining pada setiap cabang olahraga yang ada untuk mencari subjek penelitian yang sesuai dengan kriteria inklusi, yaitu tercatat sebagai atlet putri di Balai Pemusatan Pendidikan dan Latihan Olahraga Pelajar (BPPLOP) Jawa Tengah yang terletak di Kota Semarang, berusia 16-20 tahun; bersedia menjadi responden; tidak sedang menstruasi saat pengambilan data; tidak sedang mengonsumsi obat-obatan penambah darah dan obat-obatan yang mengandung kortikosteroid, glukokortikoid, dan diuretik; tidak merokok; dan mengonsumsi alkohol. Kriteria eksklusi dalam penelitian ini adalah subjek mengundurkan diri selama penelitian berlangsung.

Variabel bebas dalam penelitian ini adalah kondisi anemia defisiensi besi yang diukur lewat kadar hemoglobin dan kadar ferritin. Kadar hemoglobin merupakan jumlah protein pada sel darah merah yang membawa oksigen dalam $100 \mathrm{ml}$ darah. Kadar hemoglobin diukur menggunakan metode cyanomethemoglobin oleh petugas laboratorium dengan mengambil darah vena. Kadar hemoglobin dikategorikan normal apabila berada pada rentang 12-16 $\mathrm{g} / \mathrm{dL}$. Pengambilan sampel darah dilakukan pada pagi hari sebanyak 1 kali tanpa harus berpuasa sebelumnya. Ferritin merupakan biomarker klinis yang menunjukkan status besi dalam tubuh dan indikator utama untuk mendeteksi defisiensi besi dalam tubuh. Kadar ferritin serum didapatkan melalui sampel darah subjek dengan mengambil darah vena dan uji laboratorium menggunakan metode ELISA (Enzime-linked immunoassays). Subjek dikatakan defisiensi besi jika kadar ferritin kurang dari $15 \mu \mathrm{g} / \mathrm{L}$. Pemeriksaan darah dilakukan di Laboratorium Sentral Rumah Sakit Nasional Diponegoro (RSND) Semarang.

Variabel terikat dalam penelitian ini adalah Female Athlete Triad (FAT). Female Athlete Triad adalah kombinasi dari tiga kondisi yang berkaitan dengan olahraga. Tiga kondisi tersebut meliputi penyimpangan perilaku makan, gangguan menstruasi, dan mengalami osteoporosis. Pengukuran Female Athlete Triad ditentukan dari masing-masing hasil pengukuran penyimpangan perilaku makan, gangguan makan, dan osteoporosis. Penyimpangan perilaku makan merupakan spektrum makan yang tidak normal dan berhubungan dengan kebiasaan penyalahgunaan obat, termasuk berpuasa, melakukan binge-eating dan purging, anoreksia, bulimia dan atau menggunakan laksatif, diuretik dan pil diet. Perilaku makan yang tidak normal yang ditunjukkan dengan terpenuhinya salah satu kriteria penyimpangan perilaku makan yang disesuaikan dengan kuesioner. Penentuan penyimpangan perilaku makan mengunakan kuesioner yang diadopsi dari Eating Disorder Diagnostic Scale. Hasil wawancara menggunakan kuesioner akan dikategorikan menjadi dua, yaitu normal dan ada penyimpangan perilaku makan. Pengambilan data dilakukan oleh enumerator yang merupakan mahasiswa gizi S1 tingkat akhir di FK Undip.

Gangguan menstruasi adalah ketidak normalan status menstruasi yang dialami oleh seseorang. Pengukuran gangguan menstruasi dari subjek menggunakan kuisioner. Pertanyaan di dalam kuisioner tersebut terdiri dari usia pertama kali haid, status menstruasi saat ini, frekuensi menstruasi dan regulasi siklus menstruasi. Hasil pengisian kuesioner 
dikategorikan menjadi empat, yaitu: normal, apabila siklus menstruasi selama 21-35 hari dan mengalami menstruasi 10 - 13 kali dalam satu tahun; Primary Amenorrhea, apabila subjek tidak mengalami menstruasi sampe usia 16 tahun atau sex sekunder tidak berkembang sampai usia 14 tahun; Secondary Amenorrhea, apabila subjek tidak mengalami siklus menstruasi selama tiga bulan atau lebih setelah mengalami haid pertama; dan Oligoamenorrhea, apabila siklus menstruasi kurang dari 21 hari atau lebih dari 35 hari.

\begin{abstract}
Osteoporosis adalah penyakit yang ditandai oleh rendahnya masa tulang dan penurunan mikroarsitektural dari jaringan tulang yang menyebabkan peningkatan kerapuhan tulang dan meningkatnya risiko patah tulang. Pengukuran kepadatan tulang pada atlet putri diukur menggunakan alat Quantitative Ultrasound Bone Densitometry. Pengukuran kepadatan tulang dilakukan oleh petugas kesehatan dengan mengukur tulang tumit (tulang kalkaneus) dan jari selama \pm 1 menit. Hasil pengukuran dibagi dalam 3 kategori, yaitu: Normalapabila nilai $T$-score $-1 \leq \mathrm{SD}<2,5$; Osteopenia apabila nilai $T$-score $-2,5 \leq S D<-1$; dan Osteoporosis apabila nilai $T$-score $<-2,5 .{ }^{25}$
\end{abstract}

Analisis data dilakukan secara komputerisasi. Analisis univariat dilakukan dengan memasukkan data dalam tabel distribusi frekuensi untuk mendeskripsikan data yang diperoleh berupa distribusi dan persentase. Analisis bivariat dilakukan menggunakan uji Rank Spearman karena data berdistribusi tidak normal dengan tingkat kemaknaan $p<0,05$.

\section{HASIL}

Total subjek dalam penelitian ini berjumlah 80 orang dengan rentang usia 13-21 tahun. Hasil pengukuran kadar ferritin diketahui memiliki rentang 7-147 $\mu \mathrm{g} / \mathrm{L}$ dengan rerata $33,09 \mu \mathrm{g} / \mathrm{L} \pm 26,93$. Berdasarkan pengukuran kadar ferritin, sebanyak 15 subjek $(18,25 \%)$ mengalami anemia defisiensi besi, dan sebanyak 65 subjek $(81,25 \%)$ tergolong normal. Pengukuran kadar hemoglobin dalam penelitian ini memiliki rentang 11,4-17,3 g/d dengan rerata $13,63 \pm 1,06$. Sementara itu jika dilihat berdasarkan pengukuran kadar hemoglobin, diketahui hanya 4 subjek (5\%) yang tergolong anemia. Sebanyak 76 subjek (95\%) memiliki kadar hemoglobin yang tergolong normal.

Hasil pengukuran kepadatan tulang menunjukkan sebanyak 7 subjek memiliki $T$ score yang tergolong negatif dan sebanyak 73 subjek $(91,3 \%)$ memiliki $T$-score positif. Hasil wawancara pada subjek terkait siklus menstruasi, diketahui semua subjek memiliki usia awal menstruasi yang sesuai yaitu 65 persen di usia 11-13 tahun dan 35 persen di usia 14-16 tahun, namun berdasarkan data lamanya siklus menstruasi diperoleh sebanyak 8 subjek (10,0\%) tergolong polimenorea, yaitu siklus menstruasi < 21 hari. Sebanyak 8 subjek $(10,0 \%)$ tergolong oligomenorea, yaitu siklus menstruasi > 35 hari. Terdapat satu subjek $(1,2 \%)$ yang tergolong amenorea, yaitu tidak mengalami haid. Subjek yang tergolong eumenorea, yaitu memiliki siklus menstruasi normal, sebanyak 63 subjek $(78,8 \%)$. Sedangkan berdasarkan data perlaku makan, sebesar 37,5 persen subjek mengalami gangguan perilaku makan.

Tabel 1

Kadar Ferritin, Kadar Hemoglobin, dan Komponen Female Athlete Triad (FAT)

\begin{tabular}{lrrc}
\hline \multicolumn{1}{c}{ Variabel } & Min & Maks & Rerata \pm SD \\
\hline Kadar Ferritin $(\mu \mathrm{g} / \mathrm{L})$ & 7 & 147 & $33,09 \pm 26,93$ \\
Kadar Hemoglobin (g/dL) & 11,4 & 17,3 & $13,63 \pm 1,06$ \\
Kepadatan tulang ( $(T$-score) & $-0,5$ & 2,8 & $1,124 \pm 0,88$ \\
Siklus menstruasi (hari) & 15 & 120 & $29,7 \pm 12,6$ \\
Gangguan Perilaku Makan (Skor) & 1 & 44 & $16,59 \pm 10,08$ \\
\hline
\end{tabular}




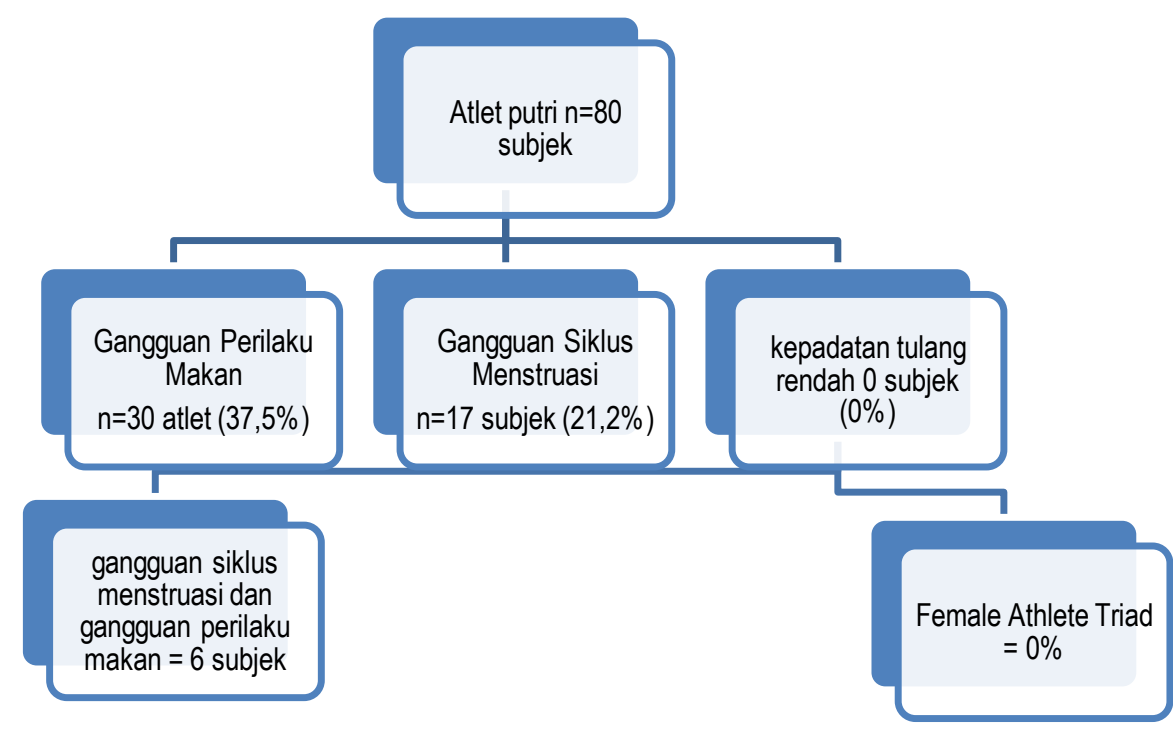

Gambar 1

Proporsi komponen Female Athlete Triad

Tabel 2

Karakteristik Subjek Penelitian

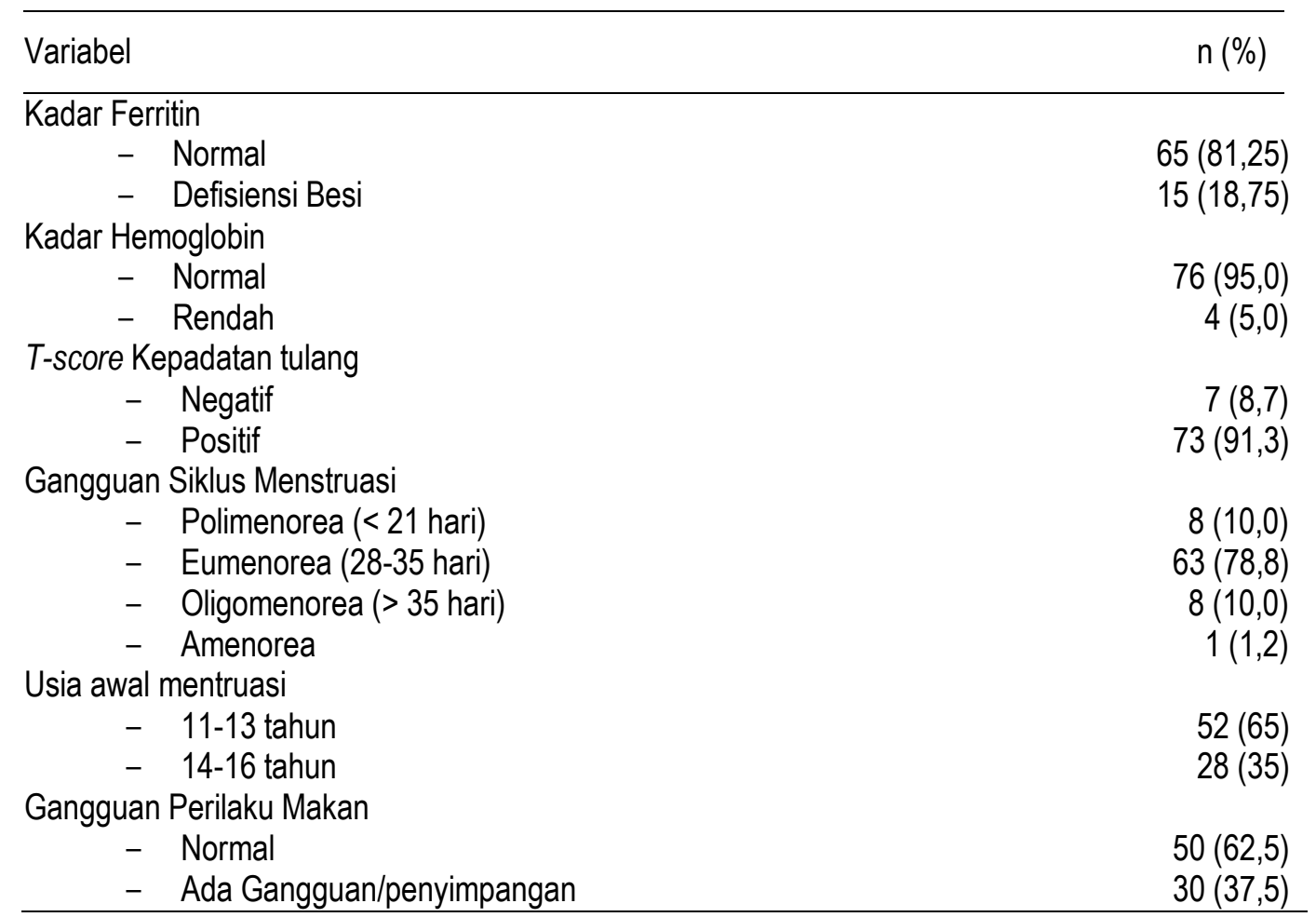


Tabel 3

Uji Hubungan Defisiensi Besi dengan Komponen Female Athlete Triad (FAT)

\begin{tabular}{lcccc}
\hline \multirow{2}{*}{ Variabel } & \multicolumn{2}{c}{ Serum Ferritin } & \multicolumn{2}{c}{ Kadar Hb } \\
\cline { 2 - 5 } & $\mathrm{p}$ & $\mathrm{r}$ & $\mathrm{p}$ & $\mathrm{r}$ \\
\hline Gangguan Siklus Menstruasi (siklus menstruasi) & 0,392 & 0,098 & 0,727 & 0,010 \\
Gangguan Perilaku Makan (hari) & 0,687 & 0,046 & 0,852 & 0,023 \\
T-score Kepadatan Tulang & $0,015^{*}$ & 0,273 & 0,002 & 0,337 \\
\hline
\end{tabular}

*signifikan $(p<0,05)$

Female athlete triad (FAT) adalah kombinasi dari tiga kondisi yang terjadi sekaligus dan saling berhubungan yang biasa dialami atlet wanita, yaitu adanya gangguan/penyimpangan perilaku makan, gangguan menstruasi, dan osteoporosis. Berdasarkan Gambar 1 diketahui tidak ada subjek yang mengalami FAT dikarenakan 100 persen kepadatan tulang subjek masih dalam kategori normal yaitu memiliki $T$-score dalam rentang $1 \leq \mathrm{SD}<2,5$. Namun, ada 7 subjek yang sudah memiliki $T$-score dengan skor negatif yang menunjukkan subjek memiliki risiko mengalami kepadatan tulang rendah. Dalam penelitian ini diketahui terdapat atlet yang memiliki 2 tanda dari komponen FAT yaitu sebanyak 6 subjek mengalami gangguan perilaku makan serta gangguan siklus menstruasi. Sedangkan bila dilihat dari 3 komponen FAT ada 1 subjek yang telah memiliki tanda gangguan penyimpangan perilaku makan, mengalami gangguan siklus menstruasi serta kepadatan tulangnya memiliki $T$-score negative (namun masih tergolong kepadatan tulang normal).

Selanjutnya dilakukan uji hubungan antara defisiensi besi dengan komponen FAT. Uji hubungan menggunakan uji korelasi Spearman, dikarenakan data berdistribusi tidak normal. Hasil uji korelasi Spearman menunjukkan ada hubungan yang signifikan antara defisiensi besi berdasarkan serum ferritin $\quad(p=0,015$; $r=0,273)$ dan kadar $\mathrm{Hb} \quad(p=0,002 ; \quad r=0,337)$ dengan kepadatan tulang atlet. Artinya semakin baik kadar serum ferritin dan kadar $\mathrm{Hb}$ subjek maka kepadatan tulang semakin optimal. Namun Hasil uji korelasi antara defisiensi besi (berdasarkan serum Ferritin dan Kadar $\mathrm{Hb}$ ) tidak menunjukkan hubungan yang signifikan dengan gangguan siklus menstruasi dan gangguan perilaku makan.

\section{BAHASAN}

Salah satu kasus defisiensi zat gizi mikro yang dilaporkan banyak terjadi pada atlet adalah defisiensi zat besi. ${ }^{4}$ Zat besi berperan penting dalam proses respirasi di dalam tubuh, baik di tingkat jaringan maupun sel. Salah satu fungsi utama zat besi adalah membentuk hemoglobin, suatu molekul penyusun utama sel darah merah yang berperan sebagai transporter oksigen dan karbon dioksida di tingkat jaringan. ${ }^{26}$ Kadar hemoglobin merupakan parameter yang perlu mendapatkan perhatian khusus pada atlet mengingat peranannya sebagai transporter oksigen yang berpengaruh terhadap performa tubuh. Defisiensi zat besi yang tidak segera mendapatkan penanganan dapat menyebabkan penurunan jumlah sel darah merah dan kadar hemoglobin dalam tubuh, kondisi ini disebut dengan anemia. ${ }^{26}$

Dalam penelitian ini diketahui sebanyak 18,25 persen (15 subjek) memiliki kadar ferritin yang tergolong defisiensi besi. Berdasarkan pengukuran kadar haemoglobin, sebanyak 5 persen (4 subjek) memiliki kadar haemoglobin yang tergolong defisiensi besi. Terdapat penelitian yang melaporkan bahwa defisiensi zat besi dengan anemia ataupun tidak pada atlet akan menyebabkan gangguan pada fisiologis tubuh, terutama pada fungsi otot dan kapasitas kerja maksimum ${ }^{5-8}$. Keadaan ini tentu akan berdampak pada penurunan performa tubuh yang merupakan kunci utama dalam pencapaian prestasi. Hal inilah yang mendasari mengapa suplementasi zat besi banyak dilakukan pada atlet, terutama yang berisiko tinggi mengalami defisiensi. Atlet endurance merupakan salah satu atlet yang berisiko tinggi terhadap defisiensi zat besi. Hal ini disebabkan karena cabang olahraga endurance memiliki 
karakteristik latihan dan pertandingan yang berintensitas tinggi dan berdurasi panjang.

Tingginya intensitas latihan ataupun pertandingan yang dibebankan dalam durasi yang panjang akan meningkatkan kehilangan zat besi melalui beberapa mekanisme, yakni peningkatan kehilangan darah lewat urin, penurunan aliran darah ke sistem pencernaan yang mengakibatkan perdarahan saluran pencernaan, peningkatan pengeluaran keringat, serta terjadinya trauma mekanis. ${ }^{27}$ Risiko kehilangan zat besi juga semakin besar terjadi pada atlet wanita akibat menstruasi. Penelitian yang dilakukan oleh Jenkinson et al. pada tahun 2012 menyebutkan faktor lainnya yang dapat menjadi penyebab defisiensi zat besi pada atlet meliputi asupan makan yang tidak adekuat, bioavabilitas besi yang rendah (atlet vegetarian), konsumsi teh dan kopi, konsumsi makanan tinggi serat, kecepatan pertumbuhan, latihan pada ketinggian, serta kondisi cedera. ${ }^{8}$

Dalam penelitian ini diketahui terdapat ada hubungan yang signifikan antara defisiensi besi berdasarkan serum ferritin $\quad(p=0,015$; $r=0,273)$ dan kadar $\mathrm{Hb} \quad(p=0,002 ; \quad r=0,337)$ dengan kepadatan tulang atlet. Artinya semakin baik kadar $\mathrm{Hb}$ dan serum ferritin subjek maka kepadatan tulangnya semakin baik. Kesehatan tulang dapat terganggu oleh kekurangan zat besi. Fungsi GH, IGF-1, dan tiroid terkait dengan FAT dapat menurun dikarenakan defisiensi zat besi dan diperparah oleh defisiensi besi terkait hipoksia. ${ }^{22}$ Didorong oleh status energi yang buruk dan gangguan fungsi reproduksi, gangguan kesehatan tulang disebut sebagai komponen FAT yang paling merusak.

Ketersediaan energi yang rendah dan fungsi reproduktif yang menurun pada atlet wanita, menginduksi metabolisme tulang proresorptif yang dicirikan oleh konsentrasi serum $\mathrm{N}$-terminal propeptide kolagen tipe I (P1NP), penanda pembentukan tulang, dan konsentrasi serum yang lebih besar dari N-terminal telopeptide (NTx) dan C-terminal telopeptide (CTx), penanda resorpsi tulang ${ }^{27}$. Metabolisme tulang pro-resorptif ini mendorong terjadinya penurunan kepadatan mineral tulang, dengan prevallensi 40 persen ${ }^{28}$ dan geometri tulang yang lebih buruk padaatlet wanita dengan amenore.Atlet wanita dengan amenore memiliki risiko tiga kali lipat lebih besar mengalami stres fraktur.29 Gangguan kesehatan tulang sangat memprihatinkan karena atlet wanita memiliki tingkat prevalensi osteoporosis hingga 13 persen dibandingkan dengan populasi umum yang hanya sebesar 2,3 persen. ${ }^{30}$

Kekurangan zat besi merupakan ancaman serius terhadap kesehatan tulang sebagai faktor risiko yang muncul untuk osteoporosis dan lebih lanjut lagi dapat membahayakan kesehatan tulang. Sebuah penelitian terkait kekurangan zat besi dengan atau tanpa anemia melalui diet pada hewan pengerat dapat menurunkan P1NP, meningkatkan NTx, dan menurunkan kepadatan tulang. ${ }^{31}$ Penelitian serupa menunjukkan bahwa defisiensi besi non-anemia juga menurunkan kekuatan tulang, struktur tulang, dan geometri tulang ${ }^{31}$. Pada manusia, transferin serum yang lebih besar dan konsentrasi feritin serum yang lebih rendah berkorelasi dengan P1NP yang lebih rendah dan konsentrasi NTx yang lebih tinggi32. Lebih lanjut, suplementasi zat besi pada wanita dengan anemia defisiensi besi menurunkan formasi tulang dan meningkatkan resorpsi tulang seperti yang ditunjukkan dengan adanya penurunan P1NP dan peningkatan konsentrasi NTx. ${ }^{32}$

\section{SIMPULAN DAN SARAN}

\section{Simpulan}

Kejadian Female Athlete Triad atau terjadinya kombinasi dari tiga kondisi yang saling berkaitan yang terjadi bersama sama pada atlet putri yaitu adanya gangguan/penyimpangan perilaku makan, gangguan menstruasi, dan osteoporosis ternyata belum ditemukan pada subjek. Meskipun sudah ada 6 subjek yang mengalami dua gangguan sekaligus yaitu gangguan perilaku makan dan gangguan siklus mentruasi, namun skor kepadatan tulangnya masih normal. Setelah dilakukan uji korelasi diperoleh bahwa defisiensi besi yang ditunijukkan berdasarkan kadar serum ferritin dan kadar $\mathrm{Hb}$ ternyata berhubungan positif dengan salah satu komponen FAT yaitu kepadatan tulang atlet, artinya semakin baik kadar serum ferritin dan kadar $\mathrm{Hb}$ subjek maka kepadatan tulang semakin optimal.

\section{Saran}

Keadaan Female Athlete Triad dan defisiensi besi pada atlet remaja putri berpotensi menurunkan performa dan status 
kesehatannya, oleh sebab itu perlu pemantauan berkala status gizi dan status anemia atlet remaja putri. Program intervensi baik edukasi gizi olahraga, pengaturan menu dan pemberian suplementasi zat besi perlu diberikan pada atlet remaja putri untuk mencegah permasalahan gizi terjadi pada periode ini.

\section{UCAPAN TERIMAKASIH}

Terimakasih kepada Departemen IImu Gizi FK UNDIP, Atlet atlet putri di Balai Pemusatan Pendidikan dan Latihan Olahraga Pelajar (BPPLOP) Jateng, Laboratorium Sentral Rumah Sakit Nasional Diponegoro (RSND) Semarang, dan Fakultas Kedokteran UNDIP yang telah mendanai penelitian ini melalui Hibah Riset pengembangan dan Penerapan (RPP) FK UNDIP tahun 2019.

\section{RUJUKAN}

1. Golden, N.H. A Review of The Female Athlete Triad. International Journal Adolescent Medicine. 2002;14(1):9-17.

2. Torstveit MK, Sundgot-Borgen J. The Female Thlete Triad : are Elite Athletes at Increased Risk? Medicine and Science in Sports and Exercise. 2005 Feb;37(2):184-93.

3. Dieny FF. Permasalahan Gizi pada Remaja Putri. Yogyakarta: Graha IImu; 2014.

4. Blancquaert L, Everaert I, Derave W. Beta-alanine supplementation, muscle carnosine and exercise performance. Curr Opin Clin Nutr Metab Care. 2015 Jan;18(1):63-70.

5. Brownlie T, Utermohlen V, Hinton PS, Haas JD. Tissue iron deficiency without anemia impairs adaptation in endurance capacity after aerobic training in previously untrained women. Am J Clin Nutr. 79(3):437-43.

6. Lukaski Hank. Vitamin and mineral status: Effects on physical performance. 2004 Aug;20(7):632-44.

7. Whiting SJ, Barabash WA. Dietary reference intakes for the micronutrients: considerations for physical activity. Appl Physiol Nutr Metab. 2006 Feb;31(1):80-5.
8. Almquist $J$, Valovich McLeod TC, Cavanna $A$, et al. Summary statement: appropriate medical care for the secondary school-aged athlete. J Athl Train. 2008;43(4):416-27.

9. Lisa D. Nutrition for exercise and sports performance. In: Krause's food and nutrition therapy. Philadelphia, USA.: Elsevier; 2008. p. 587-603.

10. Pettersson U., Stålnacke B.-M., Ahlénius G.-M., Henriksson-Larsén K., \& Lorentzon R. Low bone mass density at multiple skeletal sites, including the appendicular skeleton in amenorrheic runners. Calcified Tissue International. 1999;64(2):117-25

11. Karen B. Female Athlete Triad. BMJ. 330:244-6.

12. Jeanne F. Nichols, Mitchell J. Rauh, Mandra J. Lawson, Ming Ji, HavaShoshana Barkai. Prevalence of the Female Athlete Triad Syndrome Among High School Athletes. Arch Pediatr Adolesc Med. 2006 Feb;160(2):137-42.

13. Anne Z Hoch, Nicholas M. Pajewski, LuAnn Moraski, Guillermo F. Carrera, Charles R. Wilso, Raymond G. Hoffmann, Jane E. Schimke, David D. Gutterman. Prevalence Of The Female Athlete Triad In High School Athletes And Sedentary Students. Clin J Sport Med. 2009 Sep;19(5):421-8.

14. Loucks $A B$. Energy availability, not body fatness, regulated reproductive function in women. Exerc Sport Sci Rev. 2003 Jul;31(3):144-8.

15. Barash IA, Cheung CC, Weigle DS, Ren $H$, Kabigting EB, Kuijper JL, Clifton DK, Steiner RA. leptin is a metabolic signal to the reproductive system. Endocrinology. $1996 \mathrm{Jul} ; 137(7): 3144-7$.

16. Jorrun S, Monica K. The female football player, disorder eating, menstrual function and bone health. $\mathrm{Br} J$ Sport Med. 2007;41(1):i68-72.

17. Michelle T Barrack, Mitchell J Rauh, Hava-Shoshana Barkai, Jeanne F Nichols. Dietary Restraint and Low Bone Mass in Female Adolescent Endurance Runner. Am J Clin Nutr. 2008;87(1):3643.

18. Istiqomah NP. Hubungan Antara Faktor Eksternal dan Internal terhadap 
Kecenderungan Penyimpangan Perilaku Makan pada Atlet Wanita di SMP/SMA Negeri Ragunan Jakarta (Skripsi). [Jakarta]: Universitas Indonesia; 2009.

19. Selma AV, Edral V, Gulay DA, Cem K, Lovent $O$. Prevalence of The Female Athlete Triad in Adirne Turkey. Journal of Sports and Medicine. 2005;4:550-5.

20. Annie S, Eliane AS, Fatima PO, Beatriz GR. Female Athlete Triad in Elite Swimmers of the city of Rio de Janeiro Brazil25. Elsevier. 2009 Jun;25(6):634-9.

21. Myburgh $\mathrm{KH}$, Hutchins $J$, Fataar $A B$, Hough SF, Noakes TD. Low bone density is an etiologic factor for stress fractures in athletes. Ann Intern Med. 1990 Nov;113(10):754-9.

22. Petkus DL, Murray-Kolb LE, De Souza MJ. The Unexplored Crossroads of the Female Athlete Triad and Iron Deficiency: A Narrative Review. Sports Med. 47(9):1721-37.

23. Kemenkes RI. Laporan Hasil Riset Kesehatan Dasar (Riskesdas) Indonesia tahun 2013. Jakarta: Badan Penelitian dan Pengembangan Kesehatan Kemenkes Rl; 2013.

24. Kemenkes RI. Laporan Hasil Riset Kesehatan Dasar (Riskesdas) Indonesia tahun 2018. Jakarta: Badan Penelitian dan Pengembangan Kesehatan Kemenkes Rl; 2018.

25. RB Cook, D Collins, J Tucker, P Zioupos. Comparison of Questionnaire and Quantitative Ultrasound Techniques as Screening Tools for DXA. Osteoporosis Int. 2005;16:1565-75.

26. Escott-Stump S., Mahan L. Dietary Reference Intakes (DRIs): Recommended Intakes for Individuals, Vitamin/Mineral. In: Krause's Food \& Nutrition Therapy. 12th ed. Philadelphia: Saunders Elsevier; 2008.
27. leva Alaunyte, Valentina Stojceska, Andrew Plunkett. Iron and the female athlete: a review of dietary treatment methods for improving iron status and exercise performance. J Int Soc Sports Nutr [Internet]. 2015;12(38). Available from:

https://www.ncbi.nlm.nih.gov/pmc/articles/ PMC4596414/

28. Waters DL, Qualls $C R$, Dorin R, Veldhuis JD, Baumgartner RN. Increased pulsatility, process irregularity, and nocturnal trough concentrations of growth hormone in amenorrheic compared to eumenorrheic athletes. J Clin Endocrinol Metab. 2001 Mar;86(3):1013-9.

29. Kelsey JL, Bachrach LK, Procter-Gray E, Nieves J, Greendale GA, Sowers M, Brown BW Jr, Matheson KA, Crawford SL, Cobb KL. Risk factors for stress fracture among young female cross country runners. Med Sci Sports Exerc. 2007 Sep;39(9):1457-63.

30. Thein-Nissenbaum J. Long term consequences of the female athlete triad. Maturitas. 2013 Jun;75(2):107-12.

31. Katsumata $S$, Tsuboi $R$, Uehara $M$, Suzuki K. Dietary iron deficiency decreases serum osteocalcin concentration and bone mineral density in rats. Biosci Biotechnol Biochem. 2006 Oct; 70(10):2547-70.

32. Toxqui L, Pérez-Granados AM, BlancoRojo R, Wright I, de la Piedra C, Vaquero MP. Low iron status as a factor of increased bone resorption and effects of an iron and vitamin D-fortified skimmed milk on bone remodelling in young Spanish women. Eur J Nutr. 2014;53(2):441-8. 